\title{
A Note on the Creation Formula in Zechariah 12:1-8, Isaiah 42:5-6, and Old Persian Inscriptions
}

Christine Mitchell

christine.mitchell@usask.ca

St. Andrew’s College, University of Saskatchewan, Saskatoon, Canada

This note explores whether the influence of the Old Persian creation formula as well as its underlying theology can be seen in biblical texts. The particular focus is on Zech 12:1-8 and Isa 42:5-6. While both these texts use creation language found elsewhere in the HB corpus, the particular content and structure has strong resonances with the Old Persian texts.

One of the most frequently attested formulas in the corpus of Achaemenid royal inscriptions is the creation formula. In its Old Persian stereotypical form it reads as follows:

baga vazạrka Auramazdā

haya imām būmim adā

haya avam asmānam adā

haya martiyam adā

haya šiyātim adā martiyahạyā

haya Dārayavaum xšāyaقiyam akunauš

aivam parūvnām xšaya $\theta i y a m$

aivam parūvnām framātāram

(DNa 1-8)
A great god is Ahuramazda

Who established this earth

Who established that sky

Who established humanity

Who established peace for humanity

Who made Darius king

One king of many

One commander of many

(author's trans.) 
The text is found, with minor variations, from the reigns of Darius I, Xerxes I, Artaxerxes I, Artaxerxes II, and Artaxerxes III, from a variety of sites: Persepolis, Susa, Suez, Elvend, Van, Hamadan, and Naqsh-i Rustam. ${ }^{1}$ The sequence: deity, creation of earth and sky, creation of humanity, and creation of šiyāti for humanity, is intimately linked with the appointment of the Achaemenid king as custodian of the creation and humanity. The king is not a deity, but enjoys particular favor as the deity’s instrument. ${ }^{2}$

Beyond the creation of earth, heavens and humanity, Ahuramazda created šsiyāti for humanity. This word, often translated as "peace” or "happiness,"3 has broad cosmic overtones: it is the state of order and wholeness, opposed to the state of chaos elsewhere

\footnotetext{
${ }^{1}$ DNa, DSe, DSf, DSt (without the final two phrases), DZc (with sky before earth and without the final two phrases), DE, XPa, XPb, XPc, XPd, XPf, XPh, XE, XV, $\mathrm{A}_{1} \mathrm{~Pa}$, $\mathrm{A}_{2} \mathrm{Hc}, \mathrm{A}_{3} \mathrm{~Pa}$. For the texts, see Roland G. Kent, Old Persian Grammar, Texts, Lexicon, $2^{\text {nd }}$ ed. (New Haven, Conn.: American Oriental Society, 1953); Rüdiger Schmitt, Die altpersischen Inschriften der Achaemeniden (Wiesbaden: Reichert, 2009).

2 The seminal analysis was done by Clarisse Herrenschmidt, "Les créations d”Ahuramazda,” Studia Iranica 6 (1977): 17-58. See further, Bruce Lincoln, “Happiness for Mankind”: Achaemenian Religion and the Imperial Project (Acta Iranica 53; Leuven: Peeters 2012), 446-61.

${ }^{3}$ So Kent, Old Persian, 210.
} 
in the Old Persian inscriptions described as "the Lie” (ㅁaga $).{ }^{4}$ It shares much of the semantic field of the Hebrew שלום.

The beginning of the second משא (oracle/burden) of Zechariah, Zech 12:1-6,

contains an oracle foreseeing Judah's position as Yhwh's favored nation and the defeat of the peoples round about. The Davidic line's prominent role is emphasized in the oracle's continuation in Zech 12:7-8. The oracle begins as follows (12:1):

The word of Yhwh concerning Israel

Utterance of Yhwh

Who spreads out heavens

And establishes earth

And shapes the breath-of-humanity in its core
דבר־יהוה על ישראל

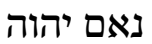
נטה שמים

ויסד ארץ ויצר רוח אדם בקרבו (MT; author's trans.)

In the Old Persian creation formula, the creation of humanity by Ahuramazda is followed immediately by the creation of šiyāti for humanity. A reader versed in the Old Persian texts would expect Yhwh after creating humanity to create שלום for humanity, and to make Darius (or some other Achaemenid) king. It is at this point that Zech 12:1-8 diverges from the sequence found in the Old Persian texts. Instead of order, Yhwh creates

${ }^{4}$ Clarisse Herrenschmidt, “Vieux-Perse šiyāti,", in La religion iranienne à l’époque achéménide (ed. Jean Kellens; Ghent: Iranica Antiqua, 1991), 13-21; P.O. Skærvø, “The Achaemenids and the Avesta," in Birth of the Persian Empire, vol. 1 (ed. Vesta Sarkhosh Curtis and Sarah Stewart; London: I.B. Tauris, 2005), 52-84; Lincoln, Happiness, 258-68. 
אבן (שים) disorder by making Jerusalem a tottering threshold (סף רעל) and a heavy stone (שים) (מעמסה) for the nations who gather to besiege it in Zech 12:2. After the creation of disorder and the defeat of the nations in vv. 2-6, then Yhwh proclaims that Jerusalem will dwell again in שלום. Finally, in Zech 12:7-8, the house of David is mentioned for the first time in the book of Zechariah; the house of David will be “like God” (כאלהים).

In its divergence from the Old Persian creation formula, the text of Zech 12:2-6 contests the cosmology/theology behind that formula. In Achaemenid theology, by creating disorder instead of order, Yhwh and his followers are the Lie, and should be destroyed by the Achaemenid king. The Achaemenids, rulers of many peoples, would bring their multi-ethnic army to bear on Jerusalem - particularly their cavalry, which was the basis of Persian might (cf. DNa, DNb) - and so it happens in Zech 12:4. However, in Zechariah, it is out of this battle that Jerusalem's salvation would come, not her destruction as the Achaemenids would have it; a play on the root שלם in Jerusalem may also be read here. The role of the house of David on that day would be comparable to the role of the Achaemenid king in the Old Persian creation texts.

The text of Zech 12:1 uses similar creation vocabulary to a number of other biblical texts (Isa 42:5-6, 44:24, 45:11-12, 51:13, 16; Jer 10:12-16 = 51:15-19; Ps 104; Job 38:4-5). The strongest linguistic parallel between Zech 12:1 and another biblical text, namely, the use of all three verbs יצר anד יסד, is with Ps 104 (vv. 2, 5, 8, 26). Of all 
of the creation texts with similar vocabulary, only Isa 42:5-6 has the same sequence of heaven-earth-humanity as Zech 12:1: ${ }^{5}$

Thus says the god Yhwh

$$
\text { כה אמר האל יהוה }
$$

Who creates the heavens and stretches them out

בורא השמים ונוטיהם

Spreads out the earth and its offspring

רקע הארץ וצאצאיה

Gives inhalation to the people upon it

נתן נשמה לעם עליה

And breath to those who walk on it

ורוח להלכים בה

I, Yhwh, have named you in righteousness

אני יהוה קראתיך בצדק

\footnotetext{
${ }^{5}$ Meyers \& Meyers see Isa 51:13-16 as the key text, along with Isa 42:5, 44:24, 45:12, Jer 10:12, 51:15, Amos 4:13, 5:8, 9:6, Pss 18:10, 104:2 and Job 9:8; they see Zech 12:1 as alluding to Genesis 2 in its order of creation (Carol L. Meyers and Eric M. Meyers, Zechariah 9-14 [AB 25C; New York: Doubleday, 1993], 311-13; cf. Marvin A. Sweeney, The Twelve Prophets, vol. 2 [Berit Olam; Collegeville, Minn.: Liturgical, 2000], 683-84, and Risto Nurmela, “The Growth of the Book of Isaiah Illustrated by Allusions in Zechariah,” in Bringing Out the Treasure: Inner Biblical Allusion in Zechariah 9-14 [ed. Mark J. Boda and Michael H. Floyd; JSOTSup 370; Sheffield: Sheffield Academic Press, 2003], 245-59); Floyd also sees allusions to Genesis 2, but also to Genesis 1 (Michael H. Floyd, Minor Prophets, Part 2 [FOTL 22; Grand Rapids, Mich.: Eerdmans, 2000], 49596); O’Brien sees Jer 10 and 51 as the linking texts, highlighting the theme of punishment of the nations (Julia M. O’Brien, Nahum Habakkuk Zephaniah Haggai Zechariah Malachi (AOTC; Nashville, Tenn.: Abingdon, 2004], 258).
} 
And I have grasped you by the hand

And I have shaped you and given you

As the people's covenant, the nations' light
ואחזק בידך

ואצרך ואתנך

לברית עם לאור גוים

(MT; author's trans.)

Unlike Zech 12:2-8, which continues after the creation formula to emphasize the disorder before Yhwh’s ultimate victory, Isa 42:6-9 continues the sequence of heaven-earthhumanity by creating a human figure, the "you" of "I have named you ... grasped you by the hand ... shaped you and given you” in v. 6. This human figure, usually understood to be the servant of 42:1-4, is the one charged with control over the entire earth. Isa 42:5-6 maintains the sequence of the Old Persian creation formula, and even has as its hero the Persian king Cyrus (so 45:1). ${ }^{6}$ The use or adaptation of the Old Persian creation formula

${ }^{6}$ Of the recent commentators, only Rex Mason and David Petersen have seen Isa 42:5 as the key text for Zech 12:1, making the link largely on vocabulary, but noting the common structure; they use the language of "doxology” to describe both texts. Petersen notes that these two texts serve as an introduction to the following verses in each case, and that “[t]he appeal to primordial creative acts provides the reason that those who are addressed should believe the prophet” (Rex Mason, “The Use of Earlier Biblical Material in Zechariah 9-14: A Study in Inner Biblical Exegesis” [Ph.D. diss., University of London, 1973], 192); David L. Petersen, Zechariah 9-14 and Malachi [OTL; Louisville, Ken.: Westminster John Knox, 1995], 110-11). However, the focus in Zechariah 12-14 is on the chaos and destruction brought about by Yhwh "on that day,” while Isaiah 40-48 has as its emphasis Yhwh's new creation. Blenkinsopp suggests that the language of Isa 42:1-9 
would be entirely consistent with the pro-Persian slant of Isa 40-48, and even if the author of Isa 40-48 did not know the Old Persian formula, the same order of heavenearth-humanity-ruler is evident. ${ }^{7}$ The omission of the ruler from the list of Yhwh's creative acts in Zech 12:1 is even more striking.

The ideology/theology of the Achaemenids is contested in Zech 12:1-8. Yhwh is posited as the creator over against Ahuramazda, and the one who will ultimately prevail over Ahuramazda's Order (마ta) as enforced by the Achaemenid king. Unlike the static paradisal universe promulgated by the Achaemenids, where chaos has already been defeated, and the present is an unending order, Zech 12:1-8 as the beginning of Zech 1214 envisions the Achaemenid order ending “on that day,” followed by the new order of Yhwh. Many recent studies of Persian-period Yehud have made use of our increasing knowledge of Persian administration and history to posit Yehud’s relationship to the Achaemenid heartland. Further work on the relationship between the Old Persian texts and Haggai-Zechariah should be done to test these results.

“fits what we know of the early Persian period” (Joseph Blenkinsopp, Isaiah 40-55 [AB 19A; New York: Doubleday, 2002], 210).

${ }^{7}$ It is important to note that the standard Old Persian order is earth and then heaven (the only exception is DZc); Ahuramazda is not Yhwh, who creates heaven and then earth. Cf. Herrenschmidt, “Créations,” 18. 